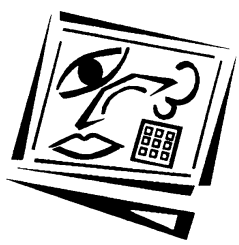

\title{
Beyond policy: Strategic actions to support ICT integration in Japanese schools
}

\author{
Michael Vallance \\ Future University, Japan
}

\begin{abstract}
Since the late 1990s technology has become a central component of national education policies in many Asian countries. In Singapore schools, for instance, technology has become central in teaching, learning and administration. On the other hand, Japanese schooling has been largely impervious to advances in educational technology. This paper aims to stimulate discourse between policy makers, teachers, researchers and the community in Japan and internationally to consider informed, meaningful strategies required for developing suitably skilled pupils for today's Digital Age. The paper begins with a summary of Singapore's technology centric education policy, called the Masterplan for IT in Education. The Japanese context is then summarised and a number of recently proposed educational reforms are discussed. It will be argued that these reforms do not lend themselves to supporting the necessary development of digital competency required of Japanese school pupils in the 21st century. To overcome the shortcomings, strategic actions to support meaningful ICT integration in education, influenced by the Singapore experience, will be proposed.
\end{abstract}

\section{Introduction}

The global changes in communication brought about by the developments in technology since the mid-1990s, particularly the Internet, have been astonishing. Recognising this, the Singapore government launched a Masterplan for IT in Education (MP1) which, at its inauguration, was considered a "... blueprint for the integration of IT in education as a strategy to meet the challenges of the 21st century" (Teo, 1997). The aim was to ensure young people were "... comfortable with new technology and be able to exploit these new technologies to venture beyond their current boundaries and open up new frontiers of knowledge" (Teo, 1997). On the other hand, Japan has been slow to reform its education policies to meet the needs of a changing economy (Craft, 2004). Due to the lack of a meaningful technology policy specifically targeting teachers and pupils in Japan, educators have little guidance on how to best inculcate a habit of digital based learning across the school curricula. This paper therefore aims to stimulate discourse between policy makers, teachers, researchers and the community to consider strategies required for developing appropriately skilled pupils in today's Digital Age.

The paper begins with a summary of a technology based education policy in Singapore. Singapore was selected due to its continuing financial investment in information technologies for business, government, education and society. The expenditure on IT in the education sector, in particular, is supported by carefully constructed policies and well-intentioned plans such as the Masterplans for IT in 
Education 1997 and 2002, and Intelligent Nation iN2015. Singapore also provides a unique model for Asian education ministries seeking to adopt, adapt and transform traditional practices with 'westernised' approaches to teaching and learning. A number of observations from the Singapore model are used to suggest strategic actions for Japan. A summary of the attempts of policy makers in Japan to develop an education system that integrates technology is then provided. It is argued that the policy statements however serve little purpose in the pragmatic application of technology in the classrooms of Japanese schools. Referencing the literature of the United Nations Educational, Scientific and Cultural Organization (UNESCO), International Society for Technology in Education (ISTE) and Kearns (2002), strategic actions that support the constructs of thinking, learning, creativity and communication are then proposed. It is anticipated that these strategic actions can be integrated in order to transform existing pedagogical practices in Japan, and also serve to support Japanese educators in their quest to become more digitally literate in their practice.

\section{Background to a technology based education policy in Singapore}

Singapore is a small island nation with a population of 4.5 million and a gross national product of US $\$ 106.3$ billion. The largest portion of Singapore's national budget is allocated to education, health and public housing. In 2001 education was allotted $22.38 \%$ of the national budget. Key education expenditures included \$2.7 billion to subsidise operations of primary, secondary and junior colleges, and $\$ 1.1$ billion to develop a technical infrastructure in educational institutions (Ministry of Finance, 2001). The emphasis in Singapore is on ability driven education in order to equip students with skills to face future challenges and promote a culture of lifelong learning (Goh, 1997). Due to the transformation in the economy brought about by the change from manufacturing to service based industries, and changes in the workplace that required an increase in traditional and digital literacy, a Masterplan for IT in Education (MP1) was launched in 1997. Even though Singapore scored well on world scholastic tests and educational rankings, the government stated that it needed to alter its education delivery; "It is crucial that the next generation is prepared for the IT world... Failure to educate them will result in society having to carry a heavy burden for the rest of their lives" (Yeo, 1999). Financially and politically, the investment in such policies by the Singapore government enables a tight control on its economy and hence its control over the state. As Ashton and Sung (1997) acknowledge, "The state coordinates the input of capital and labour to ensure that the economy moves in the direction of its political objectives" (p. 217).

\section{Singapore's first Masterplan for IT in Education (MP1)}

The aim of an educational policy that embraces technology is, ultimately, to develop a learner's digital competency (Gilster, 1997) and technological fluency (Fulton, 1998). For instance, the European Commission on Education (2002) identified digital competency as a key component of education in the 21st century; "ICT skills comprise the use of multi-media technology to retrieve, access, store, produce, present, and exchange information, and participate in networks via the Internet" (p.22). Additionally, technological fluency marries information, communication and technical skills for survival in a world increasingly rich in digital content. To inculcate these skills, Singapore's first Masterplan for IT in Education (MP1) consisted of four main goals: 
Table 1: Four main goals of MP1 (Goh, 1997)

\begin{tabular}{|l|l|}
\hline $\begin{array}{l}\text { Communication and } \\
\text { collaboration }\end{array}$ & $\begin{array}{l}\text { Teachers and pupils to communicate and collaborate with other } \\
\text { institutions. }\end{array}$ \\
\hline Innovation & Generate innovative processes in education. \\
\hline $\begin{array}{l}\text { Thinking and lifelong } \\
\text { learning }\end{array}$ & Enhance creative thinking, lifelong learning, and social responsibility \\
\hline Leadership & $\begin{array}{l}\text { Promote administrative and management excellence in the education } \\
\text { system. }\end{array}$ \\
\hline
\end{tabular}

The money spent on IT hardware and infrastructure resulted in all schools in Singapore being equipped with computers and Internet access by 2002. As the first Masterplan for IT in Education (MP1) neared its final stage in 2002 many schools began to exemplify their usage of technology. Looking through the archives of reports in the national newspaper, Ministry of Education (MOE) announcements and showcase projects, a familiar pattern emerged though: the 'better' schools were producing the 'face-saving' projects (Tripp, 2001; The Straits Times, 2003).

Investment was also provided for increasing teachers' teaching repertoires and to inculcate independent thinking and learning beyond the curriculum, supported by a Teachers Network and the Educational Technology Division of the Ministry of Education. After three years many teachers had still not been trained and most had only rudimentary IT skills, let alone the pedagogical skills to use IT effectively in learner-centred classrooms (Tsu, 2000). Also, nearly half of the new graduates from the teacher training institute in Singapore felt inadequately prepared to integrate technology in the classroom (Hu, Wong, Wong, Cheah \& D'Rozario, 2004). In addition, Deng and Gopinathan (1999) suggested that the conventional teaching practices (teacher centred content delivery and student rote learning) do not support the progressive pedagogy required by the IT Masterplan.

In fairness to the teachers who were already dealing with numerous initiatives, it could be noted that policy statements do not exemplify or clearly state what this reformed teaching practice will look like. As confirmed by Aviram (2000), "The introduction of ICT in education has often been carried out with vague and confused conceptions of the desired model of learning which the new technologies were supposed to enhance and without clear conceptions of any guiding educational values" (p. 332). In short, the use of ICT is a contentious issue with teachers. Pearson (2004) comments, "The changes in 'pedagogy' that will be sought, and the relationships between 'pedagogy' and the conditions that might help to bring them about, receive scant attention in these policy statements. Most comments about pedagogy are general in nature ('student centred' and 'active learning'), and there is seldom any recognition that the ways in which infrastructure has been installed, and what has been done - or not done - in 'basic training' are likely to impact on current pedagogical practices and attempts to change them in the future" (p.141).

\section{Singapore's second Masterplan for IT in Education (MP2)}

In April 2003 the Singapore Government announced a second Masterplan for IT in Education (MP2) to consolidate and build upon the achievements of MP1. Its goals:

- school pupils to use IT effectively for active learning;

- connections between curricula;

- instruction and assessment to be enhanced using IT; 
- teachers to use IT effectively for professional and personal growth;

- schools to have the capacity and capability in using IT for school improvement;

- there will be active research in IT in education, and there will be an infrastructure that supports widespread and effective use of IT.

Note that only one of these goals is technology focussed (i.e. a supporting infrastructure). In an effort to inculcate learner independence and digital competency there is an emphasis in MP2 on information processing and knowledge creation, development of open ended, flexible and customisable digital content, and self paced learning. Pupils in schools, for example, are expected to develop creative or innovative project work and design web based portfolios. There is thus a greater attempt by policymakers to be more specific in their desired outcomes from education where technology becomes integral. The lack of development of digital literacy in the MP1 years was acknowledged and it has been given another, less restricted opportunity to grow. For example, schools are given more independence in their selection of appropriate tools for the learning they wish to promote within their walls and the wider community. Policy makers also recognised the perception of the system by teachers who cannot use IT, simply have no idea why they should be using IT nor convinced of the value of IT; "... the proficiency goes beyond the basic use of IT as a presentation and communication tool" (Ministry of Education, 2003). Policy makers want classes to be student centred, to base lessons upon a constructivist model, teachers to "... evolve to become mediators of knowledge transformation" (Ministry of Education, 2003), and students to participate actively in their own learning.

It remains unclear what indices will be used to measure effectiveness of ICT integration. Is it more showcase projects? Is it a pupil to computer ratio? Do teachers, administrators and school principals have the knowledge and tools to measure effectiveness? As stated by Tan (1998), "As long as principals are held accountable for their schools' performance in national examinations, they cannot afford to stray too far from the mainstream curriculum" (p. 54). Policy makers in Singapore though are stepping back and passing the responsibility directly to schools: "Schools are to set their own targets, reflect and chart their own progress as well as their effectiveness of teaching integration" (Ministry of Education, 2003). The Singapore government has recognised that the 'one size fits all' approach does not reap the benefits anticipated by policy statements alone, and that individual schools need to actively participate in discussions for technology integration within their specific classroom communities, with or without Ministry of Education support.

To summarise, Singapore's policy makers have recognised some shortcomings in the IT plans and adapted to the situation of minimal change at the school level. A UNESCO report on Singapore's Masterplans provide a number of recommendations for successful implementation of future policies. These are summarised below.

- The national ICT policy must be driven by a vision that can be operationalised into realistic and manageable goals.

- A holistic approach must be taken towards the national ICT policy in education; in the case of MP1, four dimensions were identified - curriculum and assessment, learning resources, teacher development, and physical and technological infrastructure.

- There should be a division in the MOE that is responsible for coordinating and implementing the ICT Masterplan in education. 
- A good physical and technological infrastructure is a necessary condition for effective ICT integration.

- Teachers must have ready and frequent access to ICT both during and after curriculum hours, so as to access information and learning resources; prepare lesson plans; deliver their lessons; assign work and respond to their students' scripts and projects; communicate with their peers and supervisors; and perform administrative tasks.

- ICT should be placed in all teaching, learning, and even play areas in the school. This encourages the use of ICT both within and outside curriculum time, making ICT an integral part of all activities in school.

- Mobile computing offers schools opportunities that include overcoming constraints of space and giving flexibility in anytime-anywhere utilisation of ICT in schools.

- The advantages of networking of schools go beyond access to the Internet. They also include sharing of resources and collaboration within the school, among schools, and with other organisations.

It is timely to look next at the policies of Japan and attempt to marry the recommendations of UNESCO and the observations portrayed above in order to support Japan in a development of an informed ICT policy.

\section{Technology policies in Japan}

The vision and experience portrayed by the Singapore education policies are in stark contrast to those in Japan. Despite being a nation whose image is that of high technology, robotics and creative media, the actual uptake of technology in education in Japan, "remains comparatively low, and ICT does not appear as a priority in national education policy" (UNESCO, 2007). Conventional Japanese education is succinctly described by Mima (2003): "In conventional Japanese education, the curriculum is largely designed for fact-based, exam-oriented learning. In this learning process standard textbooks are used to facilitate the hierarchical flow of information from 'knowers' to 'nonknowers' and this one-way flow has been implemented in the name of improving efficiency of education. Learning activities are carried out in a closed social environment - the school - and a considerable gap exists between the subjects taught at school and the activities of real life" (p.266).

Moreover, Japanese education "is provided according to collectively established frames of reference and there is little opportunity for teachers to customise the curriculum (Latchem, Jung, Aoki \& Ozkul, 2007). Teachers are thus unprepared for any changes that may be brought about by technology adoption at schools. A Ministry of Education, Culture, Sports, Science and Technology (MEXT) survey revealed that more than $33 \%$ of teachers were unable to use a computer and less that $25 \%$ were able to provide computer instruction (Morris-Suzuki \& Rimmer, 2003). Attempts have been made to implement technology centric education policies in Japan. For instance, in 1999 the Information Technology in Education Project (ITEP) was launched with the aim that all elementary and secondary schools should use computers in teaching by 2005. Specifics of the plan included:

- Installation of computers with Internet access in all ordinary classrooms by 2005;

- Creation of training opportunities for teachers to improve their computer skills and enable them to use computers in teaching their subjects;

- Development of visual and video contents appropriate for teaching the use of computers; 
- Research and develpoment on teaching methods that use high speed networks;

- Creation of a teaching materials portal site at the National Institute for Educational Policy Research.

Table 2: The Rainbow Plan (MEXT, 2001)

\begin{tabular}{|c|c|}
\hline Strategies & Proposed action \\
\hline $\begin{array}{l}\text { 1. Improve students' basic } \\
\text { scholastic proficiency 'in } \\
\text { easy to understand } \\
\text { classes' }\end{array}$ & $\begin{array}{l}\text { Implement the } 20 \text { students per class system for fundamental } \\
\text { subjects and advance placement classes. } \\
\text { Improve classrooms in order to be able to conduct IT classes and } \\
\text { the } 20 \text { students per class system (establish "A Learning } \\
\text { Environment for the New Generation"). } \\
\text { Implement national academic achievement surveys. }\end{array}$ \\
\hline $\begin{array}{l}\text { 2. Foster youth into } \\
\text { becoming open and } \\
\text { warm hearted Japanese } \\
\text { through participating in } \\
\text { community services and } \\
\text { various programs }\end{array}$ & $\begin{array}{l}\text { Encourage youth to participate in community services and various } \\
\text { programs (or consider such a system) and establish the "Children's } \\
\text { Dream Fund". } \\
\text { Improve moral education (for example, development and } \\
\text { distribution of the "Kokoro no Note", a otebook to be used by } \\
\text { students in moral education). } \\
\text { Take actions for educational revitalisation in the home and in the } \\
\text { community. }\end{array}$ \\
\hline $\begin{array}{l}\text { 3. Improve learning } \\
\text { environment to one } \\
\text { which is enjoyable and } \\
\text { free of worries }\end{array}$ & $\begin{array}{l}\text { Enrich cultural and sporting activities (encourage school club } \\
\text { activities). } \\
\text { Take appropriate measures concerning problematic behaviors } \\
\text { among children (improvement of the suspension system and } \\
\text { measures to care such children). } \\
\text { Protect children from harmful information. }\end{array}$ \\
\hline $\begin{array}{l}\text { 4. Make schools that can be } \\
\text { trusted by parents and } \\
\text { communities }\end{array}$ & $\begin{array}{l}\text { Implement school evaluation system, including the establishment } \\
\text { of a self evaluation system and introduction of school councillors. } \\
\text { Revitalise the school board by means of parental participation and } \\
\text { disclosure of information. } \\
\text { Promote the establishment of new types of schools to fit the needs } \\
\text { of the different communities. }\end{array}$ \\
\hline $\begin{array}{l}\text { 5. Train teachers as real } \\
\text { "professionals" of } \\
\text { education }\end{array}$ & $\begin{array}{l}\text { Introduce an awards system, a bonus and a special promotion } \\
\text { system for outstanding teachers. } \\
\text { Establish a system where teachers have working community } \\
\text { experience (e.g. take working experience at companies). } \\
\text { Take appropriate measures on incompetent teachers, such as } \\
\text { teaching suspensions. }\end{array}$ \\
\hline $\begin{array}{l}\text { 6. Promote the } \\
\text { establishment of } \\
\text { universities of } \\
\text { international standard }\end{array}$ & $\begin{array}{l}\text { Reinforce university education and research functions for bringing } \\
\text { up leaders of the next generation (improve the system for } \\
\text { admitting } 17 \text { year old students into universities, universally } \\
\text { introduce a system for admitting students who have finished their } \\
\text { third year into graduate school, and establish professional schools) } \\
\text { Establish a competitive environment (grant national universities } \\
\text { the status of independent administrative corporations, promote } \\
\text { fixed term employment so that professors can transfer easily, } \\
\text { increase competitive grants). } \\
\text { Implement a strict grading system for university students and } \\
\text { focus on the teaching abilities of academics. }\end{array}$ \\
\hline $\begin{array}{l}\text { 7. Establish an educational } \\
\text { philosophy suitable for } \\
\text { the new century and } \\
\text { improve the provision for } \\
\text { education }\end{array}$ & $\begin{array}{l}\text { Review the Fundamental Law of Education and modify the Law } \\
\text { into one suitable for the new century. } \\
\text { Develop a Comprehensive Plan for the Promotion of Educational } \\
\text { Measures. }\end{array}$ \\
\hline
\end{tabular}


However, by 2003 only $29.2 \%$ of classrooms in public schools were connected to the Internet (Naito \& Hausman, 2005). In 2000 MEXT published the 'Education Reform Plan for the 21st Century', called the Rainbow Plan as it consisted of seven strategies (Table 2).

As Junior and Senior High School classrooms include, on average, 40 pupils per class, the statement 'learning environments for the new generation' in Strategy 1 was not detailed. A cause for concern here is that computer ownership of $34.9 \%$ among Japanese is quite low compared to the usage of mobile phones at $61.1 \%$ (Asia-Pacific Development Information Programme, 2007). Moreover, the uptake of technology is changing from fixed, desktop personal computers to more portable, hand held devices. A number of districts in the USA for example have been implementing a 1:1 laptop initiative for a number of years (Silvernail \& Lane, 2004). Osaka Jogakuin, a private university in Japan, provides new students with portable iPods complete with academic content relevant to their initial studies. The new generation therefore appear to be more comfortable using small, portable devices rather than large, robust, fixed PCs (Japan Media Review, 2003).

In 2001 the IT Strategic Headquarters for the Promotion of an Advanced Information and Telecommunications Network Society was established to make Japan the world's most advanced IT nation by 2005. As a result, in 2003 the promotion of the use of ICT was publicised by an e-Japan Strategy to develop an energetic, worry free, exciting and more convenient society (Naito \& Hausman, 2005). Although the policy makers recognised the need for utilisation of technology, no specific guidelines were offered in the education space beyond commenting upon the need for more support for private enterprise within public universities, and flexibility of research for public academics in the university sector. The guidance for primary and secondary education included:

- To cultivate children's ability to use information through computers or the Internet, so as to respond independently to an information and communication based society;

- High speed Internet connection in all public schools to be achieved in 2005;

- Internet connection via local area network in all classrooms to be achieved in 2005;

- One computer per person in computer classrooms. Also, a ratio of 5.4 children per computer for educational use to be achieved in 2005;

- The acquisition of IT applications to be achieved in 2005.

Of the five key statements only the first one focuses upon the learner whereas the other four are solely concerned with technology, infrastructure and access. Again a strategy appears to facilitate the funding of fixed PCs in laboratories or classrooms but does not mention laptops or other portable computing devices such as mobile phones.

As technology is aimed to be ubiquitous in the daily life of Japanese citizens, one may surmise that policy writers and decision makers at MEXT are actively observing the research and developments of other educational policies worldwide. For instance, it has been shown that Singapore is adapting its education system towards a social constructivist, problem based and project based learning philosophy, as research provides the necessary indicators of a need to change in order to continually compete economically (Luke, Freebody, Shun \& Gopinathan, 2006). Singapore is readily embracing 'western' ideas of teaching and learning in order to keep pace with changes in business practices and technology adoption. The Singapore government's 
investment in IT Masterplans and its recent Future Schools initiative (Ministry of Education, 2007) are aimed at enabling such transformation.

Unlike Singapore, where many of the political elite and ministry officials have been educated in western universities, Japan's policy makers and implementers lack direct exposure to a dialogic, conversational pedagogy that promotes inquiry and analysis. Consequently, the lack of specifics in Japan's Rainbow Plan will lead to more problems than actual solutions. For example, one may assume that the use of computers and the development of an IT infrastructure will benefit teachers and pupils of all subject disciplines. However, in the Education Reform Plan for the 21st Century the only mention of students' perceived use of technology is in the section concerning science: "We are working to increase students' desires to develop intellectual curiosity and a spirit of inquiry in the following as well as other ways so as to improve the capacity for science and technology of society as a whole" (MEXT, 2001). Three statements below summarised from the report suggest that a 'one size fits all' approach to materials development will be applied irrespective of the technological or pedagogical capabilities of the science teachers. There is no mention of English or other 'soft' subjects.

- At elementary as well as lower secondary and upper secondary schools, we emphasise experiential, problem solving approaches to learning, including observation/ experimentation and assignment study, and are working to develop the necessary facilities.

- We are using the latest results from science and technology related research institutes to prepare digital educational materials and guidance materials for teachers so that they are better able to teach science to children in easy to understand ways.

- Through partnerships with universities, research institutes, local science centres and museums, we will implement studies that familiarise students with science and technology and introduce them to insights of how human resources in science and technology are active in society.

With particular emphasis on English as a school subject, the White Paper titled Regarding the Establishment of an Action Plan to Cultivate 'Japanese with English Abilities' (MEXT, 2003) makes minimal reference to technology. There is no mention of promoting links with English speaking nations nor using the social applications of Web 2.0 tools made accessible by the networks and computer facilities being installed at schools. The themes of the report and their summaries are provided in Table 4.

New school subjects that specifically use technology such as Information Education and the Integrated Learning Period have been in place since 1999 (Shinohara, 2001) but there are barriers surrounding their implementation in any meaningful way. Walker (2003) summarises these as cultural (teachers do not wish to be seen as different), fear (teachers worry about breaking expensive equipment), authority (teachers wait until they are instructed to use technology), parental (parents demand schools prepare children for university entrance exams and see little value in creativity), beliefs (teachers, pupils and parents do not understand the value of self directed learning that would enable effective use of the abundant networked resources available), and societal (pupils success in later life most often depends upon their ability to enter the prestigious universities in Japan). Walker (2003) reaffirms the need for a dialogue among stakeholders that goes beyond the grand narrative of policy statements: "The 
conceptual framework for technology integration must be bolstered by the intellectual commitment of parents, students and teachers to use new techniques and approaches."

Table 3: Themes from White Paper 2003 (MEXT, 2003)

\begin{tabular}{|l|l|}
\hline \multicolumn{1}{|c|}{ Themes } & \multicolumn{1}{c|}{ Summary } \\
\hline Globalisation & $\begin{array}{l}\text { Globalisation extends to various activities of individuals as well as to the } \\
\text { business world. Each individual has increasing opportunities to come in } \\
\text { contact with the global market and services, and to participate in } \\
\text { international activities. It has become possible for anyone to become active } \\
\text { on a world level. }\end{array}$ \\
\hline Communication & $\begin{array}{l}\text { Furthermore, due to progress in the information technology revolution, a } \\
\text { wide range of activities, from daily life to economic activities, are being } \\
\text { influenced by the movement to a knowledge based society driven by the } \\
\text { forces of knowledge and information. Thus, there is a strong demand for the } \\
\text { abilities to obtain and understand knowledge and information as well as the } \\
\text { abilities to transmit information and to engage in communication. }\end{array}$ \\
\hline $\begin{array}{l}\text { The need for } \\
\text { English }\end{array}$ & $\begin{array}{l}\text { In such a situation, English has played a central role as the common } \\
\text { international language in linking people who have different mother tongues. } \\
\text { For children living in the 21st century, it is essential for them to acquire } \\
\text { communication abilities in English as a common international language. In } \\
\text { addition, English abilities are important in terms of linking our country with } \\
\text { the rest of the world, obtaining the world's understanding and trust, } \\
\text { enhancing our international presence and further developing our nation. }\end{array}$ \\
\hline $\begin{array}{l}\text { Recognition of the } \\
\text { lack of English } \\
\text { competency }\end{array}$ & $\begin{array}{l}\text { At present, though, due to the lack of sufficient ability, many Japanese are } \\
\text { restricted in their exchanges with foreigners and their ideas or opinions are } \\
\text { not evaluated appropriately. }\end{array}$ \\
\hline $\begin{array}{l}\text { The use of } \\
\text { technology to } \\
\text { support English }\end{array}$ & $\begin{array}{l}\text { The creation of English homepages for each school will be encouraged and } \\
\text { introduced via the system provided by the National Information Center for } \\
\text { Educational Resources. This will enhance the ability to transmit information } \\
\text { in English, serve as motivation for English learning and promote } \\
\text { international exchange utilising information technologies. }\end{array}$ \\
\hline
\end{tabular}

In addition to the barriers within schools, failure to adopt and adapt technology in mainstream education is also due to inadequate training of new instructors (Mouza, 2002). Training is most often provided in technical literacy skills focusing heavily on the hardware and software, whereas effective training has been shown to focus upon curriculum development and integration into pedagogical practices (Vallance, 2006). Acknowledging that nearly half of its teacher trainees felt inadequately prepared to effectively integrate technology in their teaching (Hu et al., 2004), Singapore's teacher training institute offered courses such as Creating Constructivist Activities with ICT, and Computer Applications in Language and Literature, as well as enrichment courses in information technology. In Japan, the policies of MEXT aim to implement reforms to foster information literacy, apply new information media in education, conduct technical training as well as develop a networked infrastructure (Shinohara, 2001). Tokyo Gakugei University, one of Japan's main teacher training institutes, offers educational technology courses such as Educational Information Processing and Education and Information Media which provide basic instruction on using technology with an emphasis on implementation in the Integrated Learning Period (Shinohara, 2001).

Moreover, there is a recognition of the need for IT courses for teachers that go beyond simply developing technology skills: "What is important in education today is not to teach how to use the technology itself. Instead, it is an important task for the Japanese school authorities to provide students with technology based media environments so 
that they can use the facilities in the studies of humanities, natural and social sciences. Otherwise, Japanese children will find themselves on the wrong side of the so-called digital divide" (Kumagai, 2000; p.17).

To conclude this section, a number of White Papers have been summarised in order to source specific guidelines on effective technology integration in Japanese schools. Commenting specifically about Japan, Bachnik stated that, "the technology revolution appears to be caught in a series of organizational 'short circuits' that sap the forward momentum of those trying to implement IT so that real forward movement is blocked" (2003, p.309). To close these short circuits, Ministry and institution leaders need to recognise and actively support educators in their efforts at ICT integration (Narita, 2003). However, it has been observed that there is dissonance between policy and implementation, that much negotiation rarely leads to significant action, and that MEXT has contributed significantly to the frustrations of potential innovators and change agents in education (Walker, 2003; Jameson, 2006; Latchem et al, 2007).

It is therefore concluded that educational guidance that can best serve all teachers and learners in developing appropriate skills for an increasing digital landscape is sorely lacking in Japan's policy documents and efforts towards institutionalised implementation. As confirmed by Bachnik, "Technology is expected to transform education in a pedagogical vacuum, rather than being incorporated into effective teaching approaches. Teachers receive little pedagogical assistance in utilizing IT since pedagogy is collapsed into technology" (2003, p.314). In effect, educators require a set of indices "different from numbers of computers, degree of access to Internet, and the development of IT infrastructure" (Bachnik, p.332). To support the development of indices, the next section proposes strategic actions for educators in Japan to support their attempts to integrate technology in mainstream classrooms.

\section{Strategic actions for the informed integration of technology}

The above sections on IT policies have been critical, portraying successes and limitations of the policies. It is therefore timely to further the debate towards better informed strategic actions for ICT integration in Japanese schools. For instance, note that the term ICT is used in preference to IT. The ' $C^{\prime}$ represents communication and this term should be recognised as communication between people 'supported by' technology. It is people who are the hub of information and technology adoption and successes, and also its failures. To begin the proposal, Kearns (2002) detailed a study of educational policies worldwide and recommended the following criteria for future policies involving technology (Table 4).

For policy makers these may prove to be useful statements of intent. Educational practitioners (i.e. teachers) on the other hand prefer details and specific guidelines on how the technology focused policies can be implemented at the classroom level.

Strategic actions are proposed in order to promote an integration of ICT that initially supports and later transforms existing practices. The proposal aims to implement the desired goals of the e-Japan and Rainbow Plan strategies through the provision of specific statements that new and current teachers can adopt in their lesson planning. This proposal (Table 5) draws from the literature of UNESCO and ISTE in their development of strategies for students to learn effectively in an increasingly digital world (ISTE, 2007). 
Table 4: Criteria for leading practice in policy for ICT in education (Kearns, 2002)

\begin{tabular}{|c|c|}
\hline $\begin{array}{l}\text { Vision and } \\
\text { leadership }\end{array}$ & $\begin{array}{l}\text { A clearly articulated vision encompasses social and economic objectives } \\
\text { while leadership is actively fostered through training, network building, } \\
\text { and in other ways. }\end{array}$ \\
\hline Strategic planning & $\begin{array}{l}\text { Strategic planning is used to connect policies and to give coherence to } \\
\text { policy directions. }\end{array}$ \\
\hline Lifelong learning & $\begin{array}{l}\text { Seen as an essential underpinning of a competitive, cohesive, and just } \\
\text { information policy. }\end{array}$ \\
\hline Monitoring progress & Indicators and targets are set with ongoing monitoring of progress. \\
\hline Foundations & $\begin{array}{l}\text { Policies directed at professional development of teachers, infrastructure } \\
\text { and online content have laid the foundations for effective use of ICT in } \\
\text { education. }\end{array}$ \\
\hline Digital literacy & $\begin{array}{l}\text { Active strategies to foster digital literacy - essential 21st century generic } \\
\text { skills (including higher order thinking and reasoning skills) for all } \\
\text { students. }\end{array}$ \\
\hline Bandwidth & $\begin{array}{l}\text { There is a strategic approach to providing affordable bandwidth for all } \\
\text { educational institutions. }\end{array}$ \\
\hline Access and equity & $\begin{array}{l}\text { There is a comprehensive and coordinated approach to the national } \\
\text { objective of providing access to the benefits of the information society for } \\
\text { all citizens. }\end{array}$ \\
\hline Innovation strategy & $\begin{array}{l}\text { To foster innovation and creative applications of ICT in education and to } \\
\text { drive cultural change about opportunities of the information and } \\
\text { knowledge society. }\end{array}$ \\
\hline $\begin{array}{l}\text { Research and } \\
\text { development }\end{array}$ & $\begin{array}{l}\text { R \& D supports the transition of education to the information society and } \\
\text { fosters dissemination of findings and maximises interaction between } \\
\text { policy, research and practice. }\end{array}$ \\
\hline Network building & $\begin{array}{l}\text { Actively built up to foster the generation and flow of new ideas and to } \\
\text { support innovation and cultural change. Networks function as learning } \\
\text { communities of practice. }\end{array}$ \\
\hline $\begin{array}{l}\text { Models and } \\
\text { exemplars }\end{array}$ & $\begin{array}{l}\text { A bank of models and exemplars of good practice has been built up } \\
\text { through case studies to benchmark good practice. }\end{array}$ \\
\hline $\begin{array}{l}\text { Community } \\
\text { strategies }\end{array}$ & $\begin{array}{l}\text { Synergies between education focused and whole of community strategies } \\
\text { support education change. }\end{array}$ \\
\hline $\begin{array}{l}\text { Transforming } \\
\text { learning }\end{array}$ & $\begin{array}{l}\text { An active dialogue has been promoted on ways of transforming learning } \\
\text { using ICT so that the community supports the vision of an information } \\
\text { and learning society. }\end{array}$ \\
\hline Partners & artnership initiatives with all stakeholders. \\
\hline
\end{tabular}

The four constructs of thinking, learning, creativity and communication in Table 5 are used to provide a meaningful focus for educators. The constructs are considered to be core skills required of school graduates in the 21st century. Maine Education Commissioner Susan A. Gendron stated: "High school graduates need a global awareness, work skills that include team-building, creativity and innovation, critical thinking and problem-solving, self-motivation and self-direction skills, information, communications and technology literacy, as well as high levels of literacy and numeracy.

If we think we can let some of our students graduate with less than that and still succeed, then we are fooling ourselves" (Partnership for 21st century skills, 2007). The corresponding strategic actions provide learning aims supporting the "... ability to transform information into knowledge using new technologies [that] can be considered the critical factor contributing to wealth and power in today's world at both the individual and national level" (Warschauer, 2007; p.43). Moreover, implementation at the classroom level needs informed support at the school and 
government level (UNESCO, 2007). The proposal should therefore be considered as strategic actions for all those involved in supporting the progress of education in modern Japanese schools.

Table 5: Strategic actions adapted from ISTE (2007)

\begin{tabular}{|l|l|}
\hline Constructs & \multicolumn{1}{|c|}{ Strategic actions } \\
\hline Thinking & $\begin{array}{l}\text { Students } \\
\text { - plan and conduct research, solve problems, and make informed decisions. } \\
\text { - identify and define problems. } \\
\text { - plan strategies of inquiry. } \\
\text { - develop and report solutions. } \\
\text { - collect and analyse data. } \\
\text { - explore alternative solutions. }\end{array}$ \\
\hline Learning & $\begin{array}{l}\text { Students } \\
\text { - locate, retrieve, organise, evaluate and present information from a variety of } \\
\text { sources and media. } \\
\text { - process data and report outcomes. } \\
\text { - select and evaluate information sources and tools based upon appropriate use. }\end{array}$ \\
\hline Creativity & $\begin{array}{l}\text { Students } \\
\text { - apply existing knowledge to construct new ideas. } \\
\text { - explore complex issues, identify trends and forecast possibilities. } \\
\text { - use technology for self expression. }\end{array}$ \\
\hline $\begin{array}{l}\text { Communi- } \\
\text { cation }\end{array}$ & $\begin{array}{l}\text { Students } \\
\text { - use digital media to interact and collaborate with peers and experts. } \\
\text { - use digital media to publish original collaborative artifacts. } \\
\text { - use a variety of digital formats to communicate effectively to multiple audiences. } \\
\text { - engage with learners of other cultures in order to develop global awareness. }\end{array}$ \\
\hline
\end{tabular}

\section{Applying the strategic actions}

To give the impression that technology has not been integrated effectively at all in Japanese schools would be misleading. For example, the Yugen Science Network utilised a Bulletin Board System (BBS) to connect elementary school pupils and young scientists. Pupils asked questions and scientists responded on the BBS. The effectiveness of the project did not necessarily depend upon examinable outcomes but upon the engaged interactions that supported pupils' reasoning, hypotheses and clarifications of scientific concepts. Typical pupil questions were, 'Does space have an end?' or, Why do rabbits jump?' Adult scientists were thus reminded of a young learner's curiosity, naivety and desires for simplistic solutions. Additionally, the interactions informed educators that science needs to be personalised if interest and motivation are to be maintained; "What the children really wanted - at least initially was not dry information and abstract data but supportive understanding. It wasn't until they felt personally recognized and secure that the active learning process started" (Mima, 2003, p.275).

At the end of a project the pupils met their online scientists. Typical responses at the end included, 'I hadn't even thought about why I had so many questions.' and ' I found things in the world is such a huge place, filled with so many amazing things. It's been great fun finding things out and building on that and learning about even more things.' (Mima, 2003). The project therefore not only supported pupils in their understanding of scientific concepts, but also informed adults how best to communicate those concepts effectively to young learners. As such, the flow of information was not transmitted but collectively developed. In other words, 
knowledge was gained by both interlocutors in the communicative process. Shared knowledge is considered an essential component of successful technology integration (Towndrow \& Vallance, 2004).

The use of computers in the Yugen Science Network enabled 'encounters' that resulted in meaningful and authentic interactions between pupils and teachers in school and a community outside the school. To illustrate a pragmatic application of current technology, a lesson outline for Junior High School English is provided (see Figure 1: Lesson outline). The purpose is to use technology as an essential component for an authentic communicative process with meaningful outcomes. Japanese teachers are advised to critique the lesson using the strategic actions outlined in Table 5, and share their thoughts with fellow professionals in their schools with view to adopting, adapting and integrating this example with their classes.

\section{Lesson outline: English, Junior High School Grade 2}

Podcasting is the creation and delivery of digital audio to portable devices such as an Apple iPod. Effective podcasting supports collaboration and communication (Belanger, 2005), and has become a popular medium for teaching and learning in some modern schools and universities in Japan (Apple, 2008). Most often podcasts are developed by instructors to broadcast content information for their students to access at leisure. Podcasts have additionally been developed by pupils to support their learning and share with fellow learners. The podcasts can be enhanced by adding multimodal interactivity with images and links to websites (Vallance \& Shibata, 2008). Adding interactivity to a podcast introduces the multimedia elements of text, audio and images for a more enlivened and creative learning experience. Passing ownership of podcasting to the students is motivating as it allows pupils to share their digital artefacts with their classmates, friends and the world.

The advantage of this multimedia podcasting strategy is that all pupils during class will be rehearsing (speaking) while the instructor can walk around and support different pupils with pronunciation and prosodic features of their English. With reference to Figure 1: Lesson Outline, in the first lesson a typed handout is provided for the podcast conversation. Some questions and personal answers are deliberately left blank for pupils to complete. Pupils then discuss, search and negotiate appropriate answers in the development of a conversational podcast. The outcome will later be exported to iTunes and an iPod, complete with chapter markers and web links. A rubric will be used to assess the pupils' process and digital outcomes.

The implementation of this lesson supports a number of the strategic actions outlined in Table 5. The pupils initially plan the process of the podcast and assign roles to the group members. In order to answer the questions initially provided, and others developed, the pupils can search the web to retrieve information about the city of Kochi. They can then organise the information for accuracy and appropriateness using an evaluation guide. Towndrow and Vallance (2004) recommend focusing upon authorship, purpose, accuracy, currency, and technical merit: "Not all sources on the web are of equal value and/or reliable and we need, therefore, to be able to evaluate the content of the web quickly and efficiently" (Towndrow \& Vallance, 2004). The pupils have an opportunity to apply existing knowledge to construct new ideas, collect and analyse information, and then present their outcomes. The pupils then report their strategy, questions and researched answers to the teacher for checking and additional 
advice. Audio, visual and text media are integrated to promote student interaction; hypothesising, clarifying, querying, testing, presenting.

\section{Course: English}

Topic: Question formation

Level: Junior High School. Grade 2 (age 14)

Lesson Objective: To practice and apply ' $\mathrm{Wh}^{* \prime}$ questions.

Duration: 200 minutes ( 4 × 50-minute lessons)

Location: A computer lab or, better still, a classroom equipped with some Internet enabled computers.

Background: Students have been introduced to the syntax of question formation. Students are familiar with using the computers to record audio and search for information online. This lesson is an opportunity to write questions and search for culturally specific answers. Students then use the information to record a conversation as a podcast which, in turn, can be uploaded online for sharing.

Procedure

- Use the following conversation to include the studied ' $\mathrm{Wh}^{* \prime}$ questions.

- $\quad$ Search the web for answers to the questions.

- Rehearse the podcast.

- Record the podcast.

- Add chapter markers with related web addresses.

- Add a photograph of podcasters.

Podcast title: Where in Japan?

Student A: Good afternoon. Welcome to 'Where in Japan' and today we are in the beautiful city of Kochi. My name is and with me are .

Student B: Hello, my name is

Student C: Hello, my name is

Student A: Tell me [name of student B], what is Kochi famous for?

Student B:

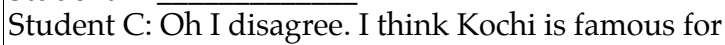

Student A: [name of student C], what Japanese dish do you recommend to visitors?

Student $\mathrm{C}$ :

Student B: Oh no. I disagree. I recommend

- Add two more 'Wh" questions and use in the podcast.

Student A: Thank you. That concludes another podcast of ‘Where in Japan'. Goodbye.

Figure 1: Lesson outline

It is envisaged that the groups will work at different rates of completion, thus allowing the teacher to communicate with each group in a unique dialogue particular to the level of success. Thus, both process and product of learning are facilitated. The process of creating the podcast (rehearsal, recording, multimedia additions and uploading to, for example, iTunes online, provides opportunities for communication and consolidation of the 'Wh' question syntax and appropriate responses. The pupils are also able to use the digital media to interact and collaborate. The content will be determined by the pupils thereby allowing self expression within a structured practice lesson. In addition, the podcast can be shared with fellow pupils at school and the wider community outside school. The technology is therefore used to facilitate a 
conversational dialogue between the pupils, their peers, the teacher and the community. The application of the recommended strategic actions is summarised in Table 6.

Table 6: Implementation of strategic actions in lesson outline

\begin{tabular}{|l|l|}
\hline \multicolumn{1}{|c|}{ Constructs } & \multicolumn{1}{c|}{ Summary of strategic actions } \\
\hline Thinking & $\begin{array}{l}\text { Pupils identify syntax, make informed decisions and report answers. Pupils } \\
\text { plan and conduct a search for information. }\end{array}$ \\
\hline Learning & $\begin{array}{l}\text { Pupils locate, retrieve, organise, evaluate and present information about } \\
\text { Kochi city. Pupils offer their own explanations, make decisions and } \\
\text { consolidate previously studied material (question formation). }\end{array}$ \\
\hline Creativity & $\begin{array}{l}\text { Pupils apply existing knowledge to construct new questions. Pupils use } \\
\text { technology (in this case, podcasting) for self expression. }\end{array}$ \\
\hline Communication & $\begin{array}{l}\text { Pupils collaborate and publish original material for a range of audiences. } \\
\text { Pupils use podcasting to interact with their peers. }\end{array}$ \\
\hline
\end{tabular}

It is acknowledged though that to implement this lesson requires a change in the transmissive approach to teaching (Thomas, 2005). It requires teachers to adopt a teaching method which supports "an iterative dialogue between instructor and learner, nurturing the ideas and skills that constitute understanding" (Laurillard, 2002, p.241). Simply using technology to mimic traditional teaching models will simply be a waste of time and resources, and in time teachers will become rightly sceptical of the additional efforts and seemingly limited benefits of ICT in their teaching. ICT integration requires not only informed strategies but also training in the implementation of these strategies; along with classroom management training, task design awareness, informed adoption, pedagogical considerations and learner assessment (Towndrow \& Vallance, 2004; Towndrow, 2007). This is indeed a daunting challenge but it is reasoned, given the desired outcomes of education generalised in policy documents, that the above lesson outline will at least provide an impetus and context for teachers, educational leaders and policy makers to implement strategic actions that focus upon the pupils and their learning when integrating technology.

\section{Conclusion}

It has been shown that the financial investment in two Singapore Masterplans for IT in Education has led to the development of an island-wide IT infrastructure and technological fluency, and that there has been an impact on teachers' pedagogical development and digital competency. However, the grand narratives of the Masterplans do not guarantee the impact on teaching and learning desired by policy makers. Teachers require specific guidance within an on going professional development program supported by schools and education ministries; "Technology integration requires a coherent vision for systematic reform, a vision that must be supported by the entire educational community" (Brooks-Young, 2007; p.1). In Japan, MEXT has failed to adopt a technology strategy that embraces change in organisational (i.e. school) structure, human resource development, funding and reward systems and, most importantly, pedagogy (Bachnik, 2003; Walker, 2003; Latchem et al., 2007).

Meaningful strategic actions for ICT integration in educational institutions in Japan can leverage upon the experiences of Singapore and begin a sustained dialogue between teachers, researchers, policy makers and the community to facilitate a better understanding of 'how' and 'why' pedagogy can be 'transformed' by 'informed' technology integration. To further progress, the dialogue should focus upon strategic 
actions to support teachers in their integration of technology at the classroom level through manageable actions and exemplification of good practices. For such conversational practices to work requires good leadership from individual school principals. Informed leadership is essential for the implementation of policies that aim to alter the traditions of pedagogical practices, pupil assessment, parent perceptions and administrative support.

In conclusion, the critical perspective used in this paper views technology not as a neutral tool (the instrumental approach) nor as a determined outcome (the deterministic approach) but as a conflicting struggle between the grand narrative of government policy makers (Luke et al., 2006) and implementation by teachers in the classrooms (Towndrow \& Vallance, 2004). This paper has introduced four constructs of thinking, learning, creativity and communication for strategic development and included associated strategic actions that can be used and customised at the individual school level by teachers. Releasing teachers from the stranglehold of a national policy bereft of specific guidance will provide opportunities for educators and learners to embrace change in understandable, meaningful and relevant ways in classrooms throughout Japan. The sooner the process of educating pupils for this new Digital Age begins, the more flexible a nation will be to economic, industrial, and social adjustments occurring throughout all of Asia, including Japan.

\section{Acknowledgements}

Many thanks to the teachers who provided valuable insights to schooling in Japan, and to Mikiko Notsu for translating documentation.

\section{References}

Apple. (2008). Apple - Education - Profiles. http:/ / www.apple.com/jp/education/profiles / [viewed $29 \mathrm{Feb} 2008$ ].

Ashton, D. N. \& Sung, J. (1997). Education, skill formation and development: The Singaporean approach. A. H. Halsey, H. Lauder, P. Brown \& A. S. Wells (Eds.), Education: Culture, economy and society. London: Oxford University Press.

Asia-Pacific Development Information Programme (2007). ICT profile - Japan. [viewed 25 Aug 2007, verified 11 May 2008] http: / / www.apdip.net/projects/dig-rev/info/jp/

Aviram, A. (2000). From 'computers in the classroom' to mindful radical adaptation by education systems to the emerging cyber culture. Journal of Educational Change, 1(4), 331-352.

Bachnik, J. M. (2003). Roadblocks on the information highway. Oxford: Lexington Books.

Belanger, Y. (2005). Duke iPod first year experience final evaluation report. http:/ / cit.duke.edu/pdf/ipod_initiative_04_05.pdf [viewed 28 Feb 2008]

Brooks-Young, S. (2007). Digital-age literacy for teachers. Applying technology standards to everyday practice. Eugene, Oregon: ISTE Publications.

Craft, L. (2004). Remade in Japan. Prism, 14(1). [viewed 26 Aug 2007, verified 11 May 2008] http:/ / www.prism-magazine.org/sept04/feature_remade.htm

Deng, Z. Y. \& Gopinathan, S. (1999). Integration of information technology into teaching: The complexities and challenges of implementation of curricular changes in Singapore. Asia Pacific Journal of Teacher Education and Development, 2(1), 29-39. 
European Commission (2002). Implementation of 'Education \& Training 2010' work programme. Working group 'ICT in education and training' progress report. [viewed 25 Aug 2007] http: / / ec.europa.eu/education/ policies / 2010/ doc/info2004.pdf

Goh, C. T. (1997). Thinking schools, learning nations. [viewed 10 Apr 2004, verified 11 May 2008] http: / / www1.worldbank.org/education/globaleducationreform/15.LinksFromHome/ 15.02.StudyTour/singapore/Singapore\%20vision.htm

Gilster, P. (1997). Digital literacy. New York: John Wiley \& Sons.

Hu, C., Wong, P., Wong, A., Cheah., H. M. \& D’Rozario, V. (2004). An evaluation of a teacher training institution's effort in preparing pre-service teachers in the use of ICT. Paper presented at ED-MEDIA 2004 - World Conference on Educational Multimedia, Hypermedia \& Telecommunications, Lugano, Switzerland, June 21-26, 2004.

ISTE (2007). National educational technology standards for students: The next generation. [viewed 25 Aug 2007, verified 11 May 2008] http:/ / www.iste.org/ AM/Template.cfm?Section=NETS

Jameson, S. (2006). Viewpoints: Change. Japanese Spotlight, Jan/Feb. [viewed 1 Mar 2008] http: / / www.jef.or.jp/journal/jef_contents_free.asp?c=1773

Japan Media Review (2003). Q\&A with Tim Clark from the Japan Internet Report, 23 March. [viewed 1 Mar 2008] http:/ / www.timclark.net/media/65.japan.media.review.html

Kearns, P. (2002). Towards the connected learning society. An overview of trends in policy for information and communication technology in education. Canberra: Department of Education, Science and Training. http:/ / www.dest.gov.au/sectors/higher_education/publications_ resources/summaries_brochures / towards_the_connected_learning_society.htm

Kumagai, F. (2000). Japanese education in the information age society. [viewed 8 March, 2008] http: / / www.unu.edu/globseminar/2001/shimane/kumagai-ft.pdf

Laurillard, D. (2002). Rethinking university teaching. A conversational framework for the effective use of learning technologies. New York: Routledge.

Latchem, C., Jung, I., Aoki, K. \& Ozkul, A. E. (2007). The tortoise and the hare enigma in etransformation in Japanese and Korean higher education. British Journal of Educational Technology. http: / / www.blackwell-synergy.com/doi/abs/10.1111/j.1467-8535.2007.00771.x. [viewed 1 Mar 2008].

Luke, A., Freebody, P., Shun, L. \& Gopinathan, S. (2006). Towards research-based innovation and reform: Singapore schooling in transition. (CRPP Research Report Series. National Institute of Education, Singapore). http: / / www.crpp.nie.edu.sg/ [viewed 25 Aug 2007, not found 11 May 2008, see Luke, A., Freebody, P., Lau, S., \& Gopinathan, S. (2005). Towards researchbased innovation and reform: Singapore schooling in transition. Asia Pacific Journal of Education, 25(1), 5-28.]

MEXT (2001). The education reform plan for the 21st century - the Rainbow Plan. [viewed 25 Aug 2007, verified 11 May 2008] http:/ / www.mext.go.jp/english/topics/21plan/010301.htm

MEXT (2003). Regarding the establishment of an action plan to cultivate 'Japanese with English abilities'. [viewed 25 Aug 2007, verified 11 May 2008].

http: / / www.mext.go.jp/english/topics / 03072801.htm

Mima, N. (2003). Online technology is not enough: Transforming the teacher-student learning process. In J. M. Bachnik (Ed.), Roadblocks on the information highway. Oxford: Lexington .

Ministry of Education (2003). Masterplan 2 for IT in Education. [viewed 30 Mar 2003, verified 11 May 2008] http: / / www.moe.gov.sg/edumall/mp2/mp2.htm

Ministry of Education (2007). Future Schools @ Singapore. [viewed 25 Aug 2007, verified 11 May 2008] http:/ / www3.moe.edu.sg/futureschools / 
Ministry of Finance (2001). Government expenditure. http:/ / www.mof.gov.sg/ [viewed 10 Apr 2003]

Morris-Suzuki, T. \& Rimmer, P. J. (2003). Cyberculture, society, and education in Japan. In J. M. Bachnik (Ed.), Roadblocks on the information highway. Oxford: Lexington Books.

Mouza, C. (2002). Learning to teach with new technology: Implications for professional development. Journal of Research on Technology in Education, 35(2), 273-292.

Naito, S. \& Hausman, B. (2005). Information and communications technology in Japan. A general overview of the current Japanese initiatives and trends in the area of ICT. Sweden: VINNOVA. [verified 11 May 2008] http: / / www.vinnova.se/ upload / EPiStorePDF/vr-05-04.pdf

Narita, M. (2003). Barriers to educational use of the Internet in a Japanese university. In J. M. Bachnik (Ed.), Roadblocks on the information highway. Oxford: Lexington Books.

Partnership for 21st century skills (2007). State initiatives. [viewed 25 Aug 2007] http: / / www.21stcenturyskills.org/

Pearson, J. (2004). Current policy priorities in information and communication technologies in education. In S. Trinidad \& J. Pearson (Eds.), Using information and communication technologies in education. Singapore: Pearson Prentice Hall.

Shinohara, F. (2001). Current trends and prospect on ICT Training in Japanese context. [viewed 14 Mar 2008, verified 11 May 2008]

http:/ / www.u-gakugei.ac.jp/ shinohar/news/kokusai/workshp/ un010310.pdf

Silvernail, D. L. \& Lane, D. M. M. (2004). The impact of Maine's one-to-one laptop program on middle school teachers and students. Maine Education Policy Research Institute, University of Southern Maine. [verified 11 May 2008\} http:/ / maine.gov/mlti/articles/research/

MLTIPhaseOneEvaluationReport2004.pdf

The Straits Times (2003). Doing more with less. Wed 29 January.

Tan, J. (1998). The marketisation of education in Singapore: Policies and implications. International Review of Education, 44(1), 47-63.

Teo, C. H. (1997). Opening new frontiers in education with information technology. [viewed 13 April 2003, verified 11 May 2008] http:/ / www.moe.gov.sg/media/speeches / 1997/280497.htm

Thomas, M. (2005). Teaching English in the laptop university. PacCALL Journal, 1(1), 80-93. [verified 11 May 2008] http:// www.paccall.org/Journal/V-1-1-papers/Thomas-englishlaptop-uni.pdf

Towndrow, P.A. (2007). Task design, implementation and assessment. Singapore: McGraw Hill.

Towndrow, P. A. \& Vallance, M. (2004). Using IT in the language classroom: A guide for teachers and students in Asia (3rd ed) Longman: Singapore.

Tripp, D. (2001). The eduQuester. Singapore: Ministry of Education. [viewed 25 Aug 2007 at http: / / www1.moe.edu.sg/eduquest, verified 11 May 2008 at http: / / www3.moe.edu.sg/edumall/rd/eduquester/default.htm]

Tsu, G.C.S. (2000). Concerns-based adoption model (CBAM) development profile of teachers in the IT Masterplan implementation. Unpublished thesis.

UNESCO (2007). ICT in education: Japan. [viewed 25 Aug 2007, verified 11 May 2008]http:/ / www.unescobkk.org/index.php?id=1381

Vallance, M. (2006). The impact of synchronous inter-networked instructor training in ICT integration. Ann Arbor: ProQuest. 
Vallance, M. \& Towndrow, P.A. (2007). Towards the 'informed use' of information and communication technology in education: a response to Adams' 'PowerPoint, habits of mind, and classroom culture', Journal of Curriculum Studies, 39(2), 219-227.

Vallance, M. \& Shibata, Y. (2008). Effective implementation of interactive podcasting for the Web 2.0 generation. The JALT CALL Journal, 4(1). (In press). http: / / jaltcall.org/journal/

Walker, N. N. (2003). Technology and Japanese high schools: Why technology integration will take time. Techlearning, 1 August. [viewed 14 March 2008, verified 11 May 2008] http:/ / www.techlearning.com/story/ showArticle.php?articleID=12803459

Warschauer, M. (2007). The paradoxical future of digital learning. Learning Inquiry. 1(1, April), 41-49. Springer New York.

Yeo, G. (1999). Digital information society in the new century. [viewed 13 April 2003, not found 11 May 2008] http:/ / www.sedb.com/edbcorp/

Dr Michael Vallance, Future University, Department of Media Architecture, 116-2 Kamedanakano-cho, Hakodate, Hokkaido, Japan, T 041-8655

Email: mvallance@mac.com Web: http:/ / web.mac.com/mvallance/

Michael Vallance is a Professor at Future University, Japan. He has a Doctorate in Education from Durham University and a Masters Degree in Computer Assisted Learning from Stirling University, UK. He is the co-author of Using IT in the Language Classroom (ISBN 0-13-127536-4) and co-editor of Teaching English to ESL Chinese students (ISBN 981-244-975-2). He is currently involved in a number of ICT enabled research projects such as Podmaps, iPod therefore iWrite, and Mindstorms in Virtual Spaces. 